ISSN : -

Inovasi Kurikulum, Februari 2004, Thn.1, Vol. 1 Nomor : 1

\title{
ANALISIS KURIKULUM: STUDI KOMPARATIF PENGEMBANGAN KURIKULUM DI JEPANG DAN INDONESIA
}

\section{Drs. Dinn Wahyudin, MA.}

\begin{abstract}
Setiap negara mempunyai sistem pendidikan nasionalnya yang disesuaikan dengan latar belakang filosofi, kebijakan, dan strategi nasional. Seperti halnya Indonesia dengan Jepang, memiliki perbedaa yang kentara diantaranya: (1) sistem desentralisasi pendidikan di Indonesia baru dimulai tahun 2002 sedangkan di Jepang sudah lama diberlakukan desentralisasi pendidikan; (2) Di Indonesia kurikulum berbasis mata pelajaran baru sedang menuju kurikuklum berbasis kompetensi, sedangkan di Jepang telah lama berdasarkan standar; (3) Di Indonesia pelajaran Agama masuk kurikulum sekolah sedangkan di Jepang tidak, kecuali sekolah yang dikelola masyarakat pemeluk agama Shinto; (4) Di Indonesia pendidikan usia dini tidak wajib, dan di Jepangpun tidak wajib tetapi sudah menjadi pilihan masyarakat mulai masuk usia 12 tahun; (5) hari belajar per tahun 250 hari, sedangkan di Jeopang 200 haru untuk SD, SLTP, SMU; (6) Pengembang kurikulum di Indonesia oleh Depdiknas (Puskur) dengan melibatkan berbagai lembaga terkait, sedangkan di Jepang oleh Monbusho, Pemerintah Daerah, Asosiasi Guru, Lembaga Riset, Orang tua dan LSM.
\end{abstract}

Keywords : Studi Komparatif, Pengembangan Kurikulum

Setiap negara memiliki sistem pendidikan nasional dan kurikulum nasional yang akan dianutnya. Ini disesuaikan dengan latar belakang filosofi, kebijakan, dan strategi pendidikan nasional yang secara keseluruhan akan dipengaruhi pula oleh sistem kenegaraan yang dianut dan tujuan yang akan diraih dalam kerangka berbangsa dan bernegara. Dalam dimensi universal, Oliva (1992) menyebut kurikulum sebagai "as a product of its time" (p.32). "Curriculum responds to and is changed by social forced, phylosophical positions, psychological principles, accumulating knowledge, and educational leadership at its moment in history." Kurikulum adalah 
produk yang dihasilkan oleh suatu peradaban masyarakat dalam ukuran dimensi waktu. Oleh sebab itu kurikulum yang berkembangpun akan sangat diwarnai oleh berbagai faktor yang terjadi di masyarakat, baik faktor ekonomi, politik, sosial budaya, maupun dimensi kemajuan sain dan teknologi. Dengan demikian, ada mata rantai yang sangat kuat antara dimensi politik suatu negara dengan perkembangan pendidikan, khususnya perkembangan kurikulum yang dianut.

Sebagai kajibanding, Hamid Hasan ( 1994, p. 179) mengatakan "Pelaksanaan kurikulum adalah pusat dari suatu upaya pendidikan. Segala citacita dan landasan teoritik yang digunakan dalam mengembangkan suatu upaya kependidikan akan teruji dalam apa yang terjadi di lapangan. Dalam perubahan kurikulum (curriculum change) adanya unsur politik seringkali merupakan penyebab utama dibandingkan dengan hasil evaluasi." Adalah suatu kenyataan yang tak bisa dielakkan bahwa perubahan kurikulum akan terjadi apabila pengambil keputusan berpendapat bahwa kurikulum yang berlaku sudah waktunya untuk diganti, dengan atau tanpa alasan akademik (Apple, 1979; Giroux, 1981, Hasan, 1988). Keterhubungan antara perubahan kurikulum dengan kekuasaan (baik politik maupun administratif adalah suatu hal yang sukar disangkal (Hasan, 1994.p. 179).

Di sisi lain, laporan NIER (1999) mengungkap secara gamblang tentang kurikulum dan kebijakan nasional dalam suatu negara. Secara umum ada lima pemicu (imperative driving) yang menjadi fokus dan perhatian utama dalam kebijakan nasional yang ditempuh dalam suatu negara, yaitu: (i) fokus pada pembangunan keterpaduan sosial (social cohesion) dan identitas nasional (national identity) dalam percaturan global untuk mempertahankan cultural heritage. Contoh : Australia dan Jerman. (ii) fokus pada pentingnya pembinaan budaya, etnis, dan nilainilai moral (moral values). Contoh : Indonesia, Malaysia. (iii) fokus pada pengembangan ekonomi masa depan (future economic well being), persaingan global/internasional. Contoh : USA, dan Australia. (iv) fokus pada persamaan kesempatan (equal opportunity dan equity) dalam gender, disabilities, income, dsb.. Misal : India, Sri Lanka. fokus pada keinginan untuk meningkatkan pencapaian siswa (students achievement). Misal : USA, New Zealand.

Laporan NIER (1999) tersebut antara lain mengungkapkan bahwa dalam model pengembangan model 
dan organisasi kurikulum secara approach, yaitu pendekatan yang umum ada dua pendekatan yang dianut dalam menyusun materi dianut oleh banyak negara, yaitu : berdasarkan outcome, atau kom(i) content atau topic based approach, petensi apa yang diharapkan dan (ii) outcome based approach. (iii) dicapaioleh siswa dalam kurun waktu gabungan antara satu dan dua.

Hal pertama, content atau topic based approach, yaitu merinci daftar topik atau masalah yang akan dibahas, tertentu dalam jenjang persekolahan yang diikutinya. Pendekatan yang ketiga, yaitu gabungan antara content atau topic based approach, dan outcome based approach.

Tabel 1 : Model Pengembangan Kurikulum antarnegara

\begin{tabular}{|c|l|c|}
\hline Nomor & Nama Negara & Pendekatan \\
\hline 1. & Australia & 2 \\
\hline 2. & China & 1 \\
\hline 3. & Fiji & 3 \\
\hline 4. & Germany (Bavaria) & 1,2 \\
\hline 5. & India & 1 \\
\hline 6. & Indonesia & 3 \\
\hline 7. & Jepang & 2 \\
\hline 8. & Malaysia & 3 \\
\hline 9. & Selandia Baru & \\
\hline 10. & USA (New York State) & menuju 2 Th. 2004) \\
\hline & & 1 \\
\hline
\end{tabular}

Keterangan :

1) Pendekatan content based

2)Pendekatan outcome/competency based

3) gabungan keduanya

kemudian disusun sebagai bentuk mata pelajaran yang akan diberikan di sekolah. Kedua, outcome based

Banyak dimensi yang mempengaruhi perkembangan pendidikan suatu negara. Dalam kajian makro 
misalnya, perkembangan pendidikan akan sangat dipengaruhi oleh berbagai dimensi antara lain : filosofis, sosial, budaya,ekonomi,ilmu pengetahuan dan teknologi, dsb. Begitu pentingnya aspek pendidikan dalam membentuk masa depan antar bangsa dan masyarakat dunia yang harmonis dan damai, UNESCO dalam "Treasure Within" (1996, p 8697) menyerukan perhatian mendalam dalam pendidikan untuk persiapan abad ke 21 yaitu dengan mengemukakan empat fondasi pendidikan dengan menyebutnya sebagai "the four pillars of education", yaitu :

(i) belajar mengetahui (learning to know) , yaitu belajar mengetahui berbagai dimensi pengetahuan sebagai dasar untuk perolehan instrumen hidup.

(ii) belajar berbuat (learning to do), sehingga orang bisa lebih mampu bertindak di lingkungannya.

(iii) Belajar hidup bersama (learning to live together), sehingga setiap orang bisa berperan serta dan bekerja sama dengan orang lain untuk kegiatan yang yang bermanfaat bagi umat manusia.

(iv) Belajar menjadi seseorang (learning tobe), sehingga setiap orang mampu mengembangkan kepribadiannnya ke arah yang lebih baik dan bertindak dengan otonom, keputusan, dan tang- gungjawab pribadi yang lebih besar.

Globalisasi yang diakibatkan oleh perkembangan teknologi komunikasi menuntut adanya kesiapan sumberdaya manusia yang memiliki kemampuan kompetitif dan adaptif dalam menghadapi berbagai persaingan dan kemajuan masyarakat. Sejalan dengan hal tersebut dalam mempersiapkan ketangguhan menghadapi AFTA 2003, maka perlu dipersiapkan sumberdaya manusia yang berkualitas, guna mempertahankan eksistensi bangsa yang mandiri, maju, dan siap untuk bersaing dengan negara-negara lain.

Seperti dilaporkan oleh UNESCO (2000, p.10-14) dalam buku laporan "Education for All 2000: Assessment Syntheses" ada enam dimensi target yang seyogyanya dicapai dalam pendidikan dasar, yaitu:(i) Expansion the early childhood care and development activities, including familiy and community intervention especially for poor children.(ii) Universal access to, and completion of primary education by the year 2000.

(iii) Improvement of learning achievement such as that an agreed percentage of an age kohort (e.g 80\% of 14 years old). Reduction the adult illiteracy rate.(iv ) Expansion of provising of basic education and 
training in other essential skills for youths and adults.(v) Increased acquisition by individuals and family of the knowledge, skills, and values required for better living.

Secara filosofis, pendidikan merupakan kebutuhan dan hak setiap manusia dalam mempersiapkan kehidupannya yang lebih baik di masa mendatang. Dengan demikian pendidikan dasar bertujuan untuk mengembangkan kepribadian, sikap, dan keterampilan dasar yang diperlukan untuk hidup dan mengikuti pendidikan lebih lanjut. Seperti dikemukakan oleh UNESCO dalam "Treasure Within" (1996) bahwa: Basic education is an indispensable 'pasport to life' that will enable people to chose what they do, to share in building the collective future and continue to learn. Education is a human right and an essential tool for achieving the goals of equality development and peace."

Makalah ini membahas dimensi kebijakan nasional, dan strategi implementasi pendidikan dua negara (Indonesia dan Jepang), dengan mengkaji sistem pengembangan kurikulum di Jepang dan di Indonesia.

\section{SISTEM KURIKULUM NASIONAL} DI JEPANG
Menurut Laporan NIER (1999), jumlah penduduk bangsa Jepang adalah 120.631 .000 orang (1990). Angka Pertumbuhan Penduduk per tahun mencapai 1,002 \%. Suatu angka pertumbuhan penduduk yang kecil dibanding dengan negara lain termasuk Indonesia. Etnis bangsa Jepang adalah Bangsa Jepang itu sendiri, dengan ada sejumlah etnis minoritas lainnya yang jumlahnya sangat kecil. Bahasa minoritas nasional adalah Bahasa Jepang, dengan demikian bangsa Jepang merupakan bahasa nasional dan bahasa ilmu pengetahuan di Jepang. Agama (mayoritas) adalah Budha dan Shinto.

Ditilik dari anggaran belanja pendidikan jumlahnya mencapai Total: US $\$ 182.828$ per tahun

dengan prosentase dari GNP sebanyak $6.3 \%$. i 


\begin{tabular}{|l|l|l|l|l|l|}
\hline Level & Govern. & Private & $\begin{array}{l}\text { Othe } \\
\text { rs }\end{array}$ & $\begin{array}{l}\text { Number } \\
\text { of } \\
\text { teachers }\end{array}$ & $\begin{array}{l}\text { Teacher : } \\
\text { Student } \\
\text { ratio }\end{array}$ \\
\hline Pre-School & NA & & & & NA \\
\hline Primary school & 24.205 & 171 & 0 & 420.901 & $1: 18.7$ \\
\hline Lower Secondary & 10,596 & 661 & 0 & 270,229 & $1: 16.6$ \\
\hline Upper Secondary: & 4,181 & 1,315 & 0 & 276,108 & $1: 18.7$ \\
-General & 2,089 & 742 & 0 & & \\
-Vocational & 1,065 & 38 & 0 & & \\
-Specialized & 14 & 38 & 0 & & \\
-Others & 19 & 1 & & & \\
(comprehensive course) & & & & & \\
-General \& Vocational & 943 & 523 & 0 & & \\
-General \& compre. & 14 & 0 & 0 & & \\
-Gen,Voc,\& Compre. & 24 & 2 & 0 & & \\
-Voc.\& Comprehen. & 13 & 1 & 0 & & \\
& & & & & \\
\hline
\end{tabular}

a. Kebijakan pendidikan di Jepang dengan perubahan masyarakat Dalam kaitannya dengan kebijakan adalah dalam bidang : Internalization kurikulum nasional, aspek yang dalam berbagai bidang perkembandominan mendapat perhatian sesuai gan media informasi, dan perkembangan sains dan teknologi. Tujuan Pendidikan Dasar (primary School) : “ to provide children ( 6-12 yrs) with 
elementary general education suited to the relevant stages of their mental and physical development and encourage to cultivate rich humanity and creativity". Sedangkan Tujuan Pendidikan Pendidikan SLTP (lower secondary School ) : "To provide children between 12-15 years with general secondary education suited to the level of their mental and physical development, based on the education given in elementary school". Peraturan (Regulations) yang berkaitan dengan kebijakan kurikulum, menyangkut : program GBPP, alokasi waktu per matpel, kegiatan belajar mengajar, penggunaan buku teks, sistem penilaian, metode untuk pencapaian siswa, pendidikan guru, dsb.

Beberapa peraturan yang mandatory bagi semua sekolah, yaitu : School Education Law menyangkut juga penentuan Tujuan pendidikan (goals and aims), lama waktu per jenjang pendidikan, dsb. Hal yang berkaitan dengan penentuan dan penggunaan buku teks untuk jenjang pendidikan dasar dan menengah ditentukan oleh Monbusho (Ministry of Education). Disain kurikulum dan standar nasional jam belajar efektif, dilakukan oleh code sebagai bentuk dalam implementasi undang-undang. Sertifikat guru dilaksanakan oleh Personnel Certification Law.

\section{b. Perubahan Kurikulum}

Beberapa alasan perubahan dalam kurikulum nasional dalam beberapa tahun terakhir, antara lain :

- Implementasi pelaksanaan "lima hari belajar" satu minggu dalam sebulan. Sedangkan setiap hari sabtu minggu kedua dalam sebulan dinyatakan hari libur, mulai berlaku September 1992.

- Mulai April 1996, implementasi "lima hari belajar" selama dua minggu dalam sebulan, sedangkan minggu kedua dan keempat dinyatakan sebagai hari libur.

- Securing of some latitude (kebebasan memilih) in children life.

- Pengenalan sistem kredit pada upper secondary school.

- Mengimplementasikan reformasi sistem pendidikan, misalnya : penggabungan (unified) lower and upper secondary school sejak tahun 1998.

- Reformasi sistem pendidikan tersebut, terfokus pada dua hal, yaitu : Pertama, "to educate people well because human beings in the only resources in the country." Kedua, "to give high respect to each child's individuality as well as to cuItivate sense of justice, sympathy, creativity, and inter- 
nationalized in order to encourage full demonstration of child's ability through his life".

- Pengembangan Kurikulum di Jepang dilakukan secara sentralisasi oleh Monbusho (centralized).

- Pihak yang terlibat dalam Pengembangan Kurikulum, yaitu : Pemerintah pusat (Monbusho), pemerintah daerah, asosiasi guru, lembaga riset, or ang tua, LSM, lembaga swasta, dsb.

- $\quad$ Different groups accomodated in curriculum process : Monbusho and accomodated by National Council such as Central council for Education; Curriculum council; The Life Long Learning Council, University Council, The Science Council, etc. Rekomendasi dari council ini sangat berpengaruh dalam. setiap sekolah diberi ke-wenangan dan akuntabilitas yang penuh dalam upaya mencapai tujuan pendidikan di sekolah. Dengan demikian otonomi sekolah dan otonomi guru telah mendapat perhatian utama. "Curriculum Organi-zation : each school curriculum is designed to show its goals/ object-tives and contents in each subjects.Curriculum is designed to be implemented by teachers. Be interpreted by teachers and im-plemented with variation. Teachers have total freedom to create curriculum". (NIER, P. 24). Integrasi kurikulum merupakan isu penting dalam sistem pendidikan nasional, antara lain : IPS dan IPA pada kelas 1 dan 2 primary school diintegrasikan ke dalam mata pelajaran "Life Environment Studies" (1989).

\begin{tabular}{|l|l|l|}
\hline Themes/Areas & How curriculum deals with & Level of schools \\
\hline $\begin{array}{l}\text { Values/international } \\
\text { understanding }\end{array}$ & $\begin{array}{l}\text { Moral education and other all } \\
\text { subjects }\end{array}$ & Elem- US \\
\hline Education for the world of work & $\begin{array}{l}\text { Industrial } \\
\text { Arts/Homemaking/Social Studies }\end{array}$ & LS \\
\hline Foreign Languages & Foreign Langguage & LS- US \\
\hline Computer/infor.Tech. & Industrial Arts/Homemaking & LS -US \\
\hline Health Education & Health \& Physical Ed. & Elem- US \\
\hline Environmental Education & Related subjects & Elem- US \\
\hline
\end{tabular}

-. -..... .............. . ..............

Jepang

Kendati Jepang menganut kurikulum yang sentralistik, namun dalam implementasi kurikulum di sekolah, kurikulum, tanpa ada jaminan sampai sejauhmana implementasi kurikulum di lapangan. Mengingat pentingnya, implementasi kurikulum dalam 
kegiatan nyata (actual curriculum), berikut ini adalah beberapa aspek yang sangat mempengaruhi implementtasi kurikulum, yaitu antara lain pengembangan profesi guru menyangkut pelaksanaan : (i) Pre service Teacher Development, dan In Service Development programmes. Untuk Pre service Teacher Development, bagi mereka yang berkualifikasi mengajar akan diberikan "Teachers Certificate". The Education Personnel Certification Law mengatur tentang pelaksanaan Pre service teacher education. (sejenis LPTK). Dan sertifikat guru tersebut diberikan calon guru yang telah memenuhi kredit point dengan mengikuti "teacher training course" pada universitas atau college; (ii) "In Service Development programmes", mencakup: kegiatan pelatihan guru yang wajib diikuti oleh para guru untuk peningkatan profesi mereka. Durasi waktu bervariasi, ditentukan oleh Local Board of education, yaitu minimum beberapa jam/hari dalam setahun. Teachers association meetings Group studies sejenis MGMP atau KKG.

Pada sumber lain, seperti diungkap dalam "Education In Japan" (Ministry of Education Japan,1998) bahwa :

- Wajib belajar (compulsory education) di Jepang adalah $6-15$ tahun. Namun demikian, APK (angka partisip[asi Kasar) untuk
SD $100 \%$, dan SLTP mencapai 100\%. Sedangkan APM SD 98\%, dan APM SLTP mencapai 99,5\%.

- Prosentase pengeluaran pemerintah untuk pendidikan dihitung dari total anggaran pemerintah pada tahun 1995 mencapai 9,9\%. Bandingkan dengan posisi Indonesia pada tahun yang sama hanya mencapai 6,6 \%.

\section{PERBANDINGAN KURIKULUM NASIONAL DI INDONESIA DAN JEPANG}

Seperti telah disebutkan bahwa perkembangan kurikulum di akhir abad ke-20 dan awal abad ke 21 menunjukkan fenomena yang menarik karena adanya arus yang berbeda antara apa yang akan dilakukan di Indonesia dengan apa yang terjadi di beberapa negara seperti Jepang. Para pengembang kurikulum di Indonesia mengarah kepada proses desentralisasi, sedangkan pengembangan kurikulum di Jepang mengarah pada suatu standar nasional. Proses pengembangan standar nasional di negara maju (Jepang) tersebut didasarkan pada kajian filosofis, teoritis, dan kenyataan empirik mengenai kualitas pendidikan di negara yang bersangkutan.

Perbandingan Pengembangan Kurikulum Indonesia Jepang

\begin{tabular}{|c|c|c|}
\hline Indonesia & Jepang & Catatan/Komentar \\
\hline $\begin{array}{l}\text { 1. Sistem pendidikan: } \\
\text { Mulai tahun } \quad \text { 2002, dari } \\
\text { sentralisasi r menuju } \\
\text { desentralisasi . } \\
\text { Standar kurikulum Nasional : }\end{array}$ & $\begin{array}{l}\text { Sentralisasi pendidikan. } \\
\text { oleh Monbusho (centralized). } \\
\text { Standar Kurikulum : berubah } \\
\text { dari syllabus approach ke } \\
\text { curriculum framework dengan }\end{array}$ & $\begin{array}{l}\text { Walaupun kurikulum dilakukan secara } \\
\text { sentralisasi oleh Monbusho,pihak yang } \\
\text { terlibat dalam Pengembangan Kurikulum, } \\
\text { yaitu : Monbusho, pemerintah daerah, } \\
\text { asosiasi guru, lembaga riset, orang tua, }\end{array}$ \\
\hline
\end{tabular}


Berikut ini adalah kajian Proses \begin{tabular}{rl|ll|lll} 
6. Hari belajar per tahun (SD- & 201 days/years & (SD-SLTP- & Di Jepang, disesuai
\end{tabular} pengembangan kurikulum antara SLTP-SMU) : 250-250-250 Indonesia dengan Jepang :

\begin{tabular}{|c|c|c|}
\hline SLTP-SMU) : 250-250-250 & SMU). & $\begin{array}{l}\text { kesepakatan sekolah/ daera } \\
\text { mengurangi jumlah. }\end{array}$ \\
\hline $\begin{array}{l}\text { 7. Pembagian waktu : catur } \\
\text { wulan ( } 3 / \text { tahun), tahun } 2003 \\
\text { akan menjadi per semester }\end{array}$ & Semester dan tri wulan & \\
\hline $\begin{array}{l}\text { 8. Perubahan mata pelajaran } \\
\text { (5 tahun terakhir : } \\
\text {-Civic Educuation } \\
\text {-Science technology } \\
\text {-Computer Science } \\
\text {-Local Curriculum }\end{array}$ & Tidak ada perubahan & $\begin{array}{l}\text { Di Jepang, penekanan pada } \\
\text { creativity. }\end{array}$ \\
\hline $\begin{array}{l}\text { 9. Pengembang Kurikulum: } \\
\text { Depdinas (Puskur) dengan } \\
\text { melibatkan berbagai lembaga } \\
\text { terkait seperti :institusi terkait, } \\
\text { universitas, asosiasi profesi, } \\
\text { guru, kepala sekolah, dsb. }\end{array}$ & $\begin{array}{l}\text { Monbusho,pihak yang terlibat } \\
\text { dalam Pengembangan } \\
\text { Kurikulum, yaitu : Monbusho, } \\
\text { pemerintah daerah, asosiasi } \\
\text { guru, lembaga riset, orang } \\
\text { tua, LSM. }\end{array}$ & $\begin{array}{l}\text { Kendati di jepang bercirikar } \\
\text { sekolah diberi kewenangan } \\
\text { mengimplementasikan } \\
\text { kurikulum, sesuai dengan } \\
\text { pusat. }\end{array}$ \\
\hline 10.Pendekatan & khusus & $\mathrm{D}$ \\
\hline
\end{tabular}


Dalam konteks perbandingan kuri- ilmu pengetahuan. Sedangkan kulum antarbangsa, terutama dalam dalam konteks nasional, banyak kaitan antara pengembangan kuri- pihak yang menyatakan bahwa kulum di Indonesia dan Jepang, keterpurukan bangsa ini refleksi dari pengembangan kurikulum merupa- carut marutnya sektor ekonomi dan kan suatu proses yang dinamis politik. Akibat dari krisis moneter yang seiring dengan dinamika dan berkepanjangan sejak tahun 1997, pertumbuhan masyarakat itu sendiri. menjadikan titik awal keterpurukan Pengembangan kurikulum nasional bangsa Indonesia. $\mathrm{Di}$ sisi lain, antar negara, akan sangat di- gonjang ganjing politik yang pengaruhi oleh beberapa faktor dipamerkan oleh para politisi kita, antara lain falsafah, politik, sosial, terkadang membuahkan hasil yang ekonomi, budaya, dan perkembangan sangat merugikan. Yaitu semakin mengukuhkan bangsa ini sulit untuk keluar dari krisis multidimensi yang melilit hampir pada semua rongga bangsa. Data ataupun informasi hasil kajian riset yang ditampilkan berbagai lembaga dunia seperti WHO, UNDP, IMD, Bank Dunia, dsb. tentang posisi bangsa Indonesia dibandingkan dengan bangsa lain di dunia, seyogyanya tak sebatas untuk kepentingan rambu-rambu penyedap 
orasi para pejabat ataupun sebatas cuplikan literatur untuk kajian ilmiah yang ditampilkan para pemikir kita. Sepatutnya, kajian riset yang menggambarkan nada suram bangsa ini, dapat dijadikan momentum dan suntikan semangat agar bangsa kita dapat bangkit dan tidak terbuai dalam keterpurukan dan mimpi buruk yang berkepanjangan.

Di Indonesia, perkembangan kurikulum seiring dengan dinamika dan tuntutan kebutuhan. Sebut saja misalnya Kurikulum 1975, kurikulum 1984, kurikulum 1994, dan Supplemen Kurikulum 1999, sampai tahun 2004 yang memberlakukan Kurikulum berbasis kompetensi (KBK). Semua itu, diakui atau tidak akan sangat dipengaruhi oleh berbagai faktor, antara lain juga faktor politik. Saat ini, kurikulum pendidikan nasional yang dianut oleh jenjang pendidikan dasar, menengah, dan kejuruan adalah Kurikulum pendidikan Nasional 1994. Walaupun sejak beberapa tahun yang lalu, telah ada upaya penyempurnaan kurikulum 1994, dengan menerbitkan suplemen kurikulum 1999. Kurikulum pendidikan 1994, pada dasarnya merupakan kurikulum yang content based, yang berbeda dengan kurikulum yang berbasis kompetensi yang akan diterapkan pada tahun 2004.
Secara politis, sesuai dengan kebijakan pendidikan nasional yang akan dipilih, antara lain melalui implementasi UU nomor 22 tahun 1999 tentang Otonomi Daerah, dan PP nomor 25 tahun 2000 pembagian kewenangan antara Pusat dan daerah, maka membawa konsekuensi baru dalam rumusan kebijakan pendidikan, antara lain berkembangnya pemikiran dan kebijakan baru untuk melaksanakan desenralisasi pendidikan. Dalam dimensi politis, kaitannya dengan kurikulum pendidikan nasional, transisi dari sentralisasi ke desentralisasi pengeolaan pendidikan, membawa konsekuensi logis antara lain pada pembagian kewenangan antar pengelola pendidiklan di pusat (nasional), propinsi, dan kewenangan kabupaten/kota.

Saat ini, kurikulum pendidikan nasional yang dianut oleh jenjang pendidikan dasar, menengah, dan kejuruan adalah Kurikulum pendidikan Nasional 1994. Walaupun sejak beberapa tahun yang lalu, telah ada upaya penyempurnaan kurikulum 1994, dengan menerbitkan suplemen kurikulum 1999. Kurikulum pendidikan 1994, pada dasarnya meupakan kurikulum yang content based, yang berbeda dengan kurikulum yang berbasis kompetensi 
yang akan diterapkan pada tahun 2004.

Sesuai dengan kebijakan pendidikan nasional yang akan dipilih, antara lain melalui implementasi UU nomor 22 tahun 1999 tentang Otonomi Daerah, dan PP nomor 25 tahun 2000 pembagian kewenangan antara Pusat dan daerah, maka membawa konsekwensi baru dalam rumusan kebijakan pendidikan, antara lain berkembangannya pemikiran dan kebijakan baru untuk melaksanakan desentralisasi pendidikan.

Dalam kaitannya dengan kurikulum pendidikan nasional, transisi dari sentralisasi ke desentralisasi pengelolaan pendidikan, membawa konsekuensi logis antara lain pada peta kewenangan mana yang masih dikelola pusat (nasional), propinsi, dan kewenangan kabupaten/kota dalam mengelola pendidikan. Standar Based Education yang diterapkan di Indonesia, tampaknya masih akan dilakukan oleh Pusat (Depdiknas) c.q Puskur, dengan melibatkan semua unsur terkait baik dunia industri, perguruan tinggi, lembaga dan asosiasi profesi (PGRI,ISPI,dsb), lembaga terkait, termasuk unsur sekolah (guru, kepala sekolah, dan siswa).

\section{KESIMPULAN}

a. Setiap negara memiliki sistem pendidikan nasional yang akan dianutnya. Ini disesuaikan dengan latar belakang filosofis, kebijakan, dan strategi pendidikan nasional yang secara keseluruhan akan dipengaruhi pula oleh sistem kenegaraan yang dianut dan tujuan yang akan diraih dalam berbangsa dan bernegara.

b. Globalisasi yang diakibatkan oleh perkembangan teknologi komunikasi masing-masing menuntut adanya kesiapan sumberdaya manusia yang memiliki kemampuan kompetitif dan adaptif dalam menghadapi berbagai persaingan dan kemajuan masyarakat. Sejalan dengan hal tersebut dalam mempersiapkan ketangguhan. Fenomena tersebut secara langsung memberi warna dan dampak dalam kajian studi komparatif sistem pendidikan nasional yang dianut.

c. Pendidikan nasional di Jepang, aspek yang dominan yang mendapat perhatian sesuai dengan perubahan masyarakat Jepang adalah dalam bidang: Internalization dalam berbagai bidang, perkembangan media informasi, dan perkembangan sains dan teknologi.

d. Kendati di Jepang, wajib belajar ditetapkan sampai dengan se- 
kolah lanjutan pertama (SLTP), namun tingkat partisipasi masuk SLTA ISMU cukup tinggi. Ini artinya kesadaran masyarakat Jepang untuk belajar sangat tinggi (98\%). Hal yang agak berbeda dengan di indonesia dimana angka partisipasinya masuk SLTA hanya sekitar $60 \%$.

e. Persoalan kebijakan kurikulum yang akan dipilih, bukan terletak pada pilihan apakah pendekatan content based atau competency based yang akan digunakan, namun lebih pada akuntabilitas dan kesinambungan program kurikulum, dari mulai tataran ide, dokumen, implementasi, dan evaluasi kurikulum yang akan digunakan dalam suatu negara. Di Jepang misalnya, menggunakan pendekatan sentralistik dengan warna subject content yang kental, namun perencanaan dan implememtasi kurikulum dilaksanakan secara sangat bertanggungjawab, di tataran makro ataupun di level mikro di sekolah dan kelas. Hasilnya Jepang unggul dalam SDMnya. Dan menjadikan negara Matahari tersebut maju pesat, dengan tidak meninggalkan ciri budayanya.

\section{Daftar Pustaka}

Bidwell, Charles dan Robert Dreeben. 1992. "School Organization and Curriculum" dalam Handbook of Research On Curriculum. Editor : Philip W. Jackson. New York : Macmillan

Hasan, S.H., (2002). Sari Perkuliahan Studi Perbandingan Kurikulum. Bandung : PPS UPI, --o-, (1990). Evaluasi Kuri- kulum. Jakarta : Depdikbud Jakarta

Jalil, F. dan Supriadi, D., (2000).. Reformasi Pendidikan dalam Menyambut Otonomi Daerah. Yogyakarta: Adi Cita.

Ministry of Education of Japan. (1989). Education in Japan in Glance. Tokyo: Ministry of Education.

National Institute for Educational Research (NIER). (1999). An International Comparative Study of School Curriculum. Tokyo: NIER Publication.

Nur, A. S., (2001). Lima belas Negara Perbandingan Sistem Pendidikan. Bandung : Lubuk Agung.

Jackson, P. W., (1992). Handbook of Research On Curriculum. New York: Mcmillan Publishing Company. 
ISSN : -

Inovasi Kurikulum, Februari 2004, Thn.1, Vol. 1 Nomor : 1

Oliva, P. F., (1992). Developing Sukmadinata, N. Sy., (2000).. Curriculum. New York: Harper Collins Publisher. Pengembangan Kurikulum. Teori dan Praktek. Bandung : PT. Remaja Rosda Karya.

Schubert, W., (1986). Curriculum :

Perspective, Paradigma, and Possibilities. New York : Mcmillan Publishing Co.

Thompson, Audrey. The Adult and Curriculum. Philosophy of Education. (1998). Avaiable at http://x.ed.uiuc.edu/EPS/PESYearbook/thompson.ht. 